\title{
Human and Climate Effects on the Hamoun Wetlands
}

\author{
SAEIDEH MALEKI \\ Department of Natural Resources, University of Zabol, Zabol, Iran \\ SAEID Soltani Koupaei AND Alireza SofFianian \\ Department of Natural Resources, Isfahan University of Technology, Isfahan, Iran \\ SASSAN SAATCHI \\ Jet Propulsion Laboratory, California Institute of Technology, Pasadena, California \\ SAEID POURMANAFI \\ Department of Natural Resources, Isfahan University of Technology, Isfahan, Iran \\ VAHID RAHDARI \\ Hamoun International Wetland Research Institute, University of Zabol, Zabol, Iran
}

(Manuscript received 17 July 2018, in final form 21 April 2019)

\begin{abstract}
Negative impacts of climate change on ecosystems have been increasing, and both the intensification and the mitigation of these impacts are strongly linked with human activities. Management and reduction of human-induced disturbances on ecosystems can mitigate the effects of climate change and enhance the ecosystem recovery process. Here, we investigate coupled human and climate effects on the wetland ecosystem of the lower Helmand basin from 1977 to 2014. Using time series climate-variable data and land-use changes from Landsat time series imagery, we compared changes in ecosystem status between the upstream and downstream regions. Results show that despite a strong and prolonged drought in the region, the upstream region of the lower Helmand basin remained dominated by agriculture, causing severe water stress on the Hamoun wetlands downstream. The loss of available water in wetlands was followed by large-scale land abandonment in rural areas, migration to the cities, and increasing unemployment and economic hardship. Our results suggest that unsustainable land-use policies in the upstream region, combined with synergistic effects of human activities and climate in lower Helmand basin, have exacerbated the effects of water stress on local inhabitants in the downstream region.
\end{abstract}

\section{Introduction}

Historical records of precipitation and drought indices all show increased aridity since 1950 over many land areas (Dai 2013; Kahsay 2016). The droughts are mainly due to the extreme climate variability mixed with higher temperatures due to warming in many areas of the world. Long periods of drought, particularly in semiarid and arid regions, a decline in water input from extended precipitation anomalies, an increase in atmospheric water demand, and faster evaporation of water due to

Corresponding author: Saeideh Maleki, sahraa62@yahoo.com warming can readily create cascading effects on water resources (Barrios et al. 2008; Ye and Grimm 2013). Since semiarid and arid regions are already water limited, any decrease in water supplies from droughts rapidly threatens both people and wildlife (El-Khoury et al. 2015; Li et al. 2009). Furthermore, human activities in terms of land degradation, unsustainable land-use changes and water resource management, and inefficient irrigation methods significantly exacerbate the effects of drought (Wu et al. 2013; Zhou et al. 2013; Zhao et al. 2016; Bortels et al. 2011). Coupled human and climate (CHC) effects are becoming increasingly important in ecosystem studies and in the 
sustainable management of land and water use (MacMartin et al. 2014; Rowhani et al. 2011; Zhang et al. 2013; Wang et al. 2009) Taking CHC into account allows the development of mitigation strategies on human activities in order to alleviate some of the negative impacts of climate change (Fu et al. 2017).

In this paper, we study $\mathrm{CHC}$ effects and trends in climate and land-use change in a damaged arid ecosystem in southeast Iran, including the Hamoun wetlands in the lower Helmand basin. Because of their location in the middle of a vast desert, the Hamoun wetlands are a critical water source not only for local communities but also for migratory and breeding birds (Maleki et al. 2016). The majority of inhabitants in the area are employed in agriculture, fisheries, and handicraft production, with their income depending strongly on water resources and ecosystem services. However, degradation of the ecosystem from droughts and water shortage combined with the mismanagement of land use from poor irrigation systems and harvesting practices have caused large-scale poverty, unemployment, and migration to urban areas (Partow 2003). Therefore, to maintain and conserve the services of the Hamoun wetlands, it is necessary to design and implement conservation policies that take $\mathrm{CHC}$ into account. Before making decisions about the problem, the factors that affect water limitation should be investigated. Then, sustainable polices to achieve climate adaptation and mitigation, wetland restoration, and human development in the region can be designed (Fu et al. 2017).

Despite the importance of the Hamoun wetlands, field surveys on the status of the ecosystem and its health and integrity are difficult and rare due to its location between Iran and Afghanistan and conflicts in Afghanistan (UNEP 2002; FAO 2015). Most studies have been focused on the Iranian side of the wetlands and have produced a variety of datasets and results. From the cooperation framework between the governments of the Netherlands and Iran, an Integrated Water Resources Management (IWRM) study has been carried out in the Sistan province of Iran, where most of the Hamoun wetlands are located. This cooperation also included the Sistan flood warning and emergency plan run by WL-Delft Hydraulics in 2003 that provided extensive data on the region's water resources. Our previous work in this area focused on wetland restoration and the reduction of the negative impacts of droughts in the region (Maleki et al. 2018). Few studies have focused on wetland habitat condition and investigated waterbird habitat suitability (Maleki et al. 2016) and population during the dry and wet years (Behrouzi-rad 2009). The restoration and sustainable use of the shared wetlands has been studied by the United Nations Development Program (UNDP) office in Iran. The socioeconomic impacts of the Hamoun wetlands and its ecosystem on the region have been evaluated (Dahmardeh et al. 2009; Imandoust and Ghoreishi 2016). These studies together provide some survey data on the status of the Hamoun wetlands and its impact on the people who are dependent on its services. However, there has been limited work focused on understanding the coupled human and climate effects on the Hamoun wetlands.

In this paper, we investigate the changes in land use and land cover (LU-LC) and climate variability of the Hamoun wetlands located in Iran in the lower Helmand basin. Our study will address whether human activities are managed in light of recent changes in climate or whether new policies for sustainable use and development are necessary to take into account the coupled human and climate. We use time series data from Landsat and the Climatic Research Unit (CRU) of the University of East Anglia (United Kingdom) to study long-term changes (1977-2014) and synergistic effects of $\mathrm{CHC}$ in this area. The study also included socioeconomic factors that represent the well-being of the inhabitants and those dependent on the ecosystem services of the Hamoun wetlands and the lower Helmand basin. The paper aims to answer three questions: (i) How are climate factors changing across the Hamoun wetlands? (ii) To what extent are local human activities exacerbating the effects of climate change? (iii) What is the synergistic effects of human and climate effects on ecosystem degradation?

\section{Material and methods}

\section{a. Study area}

The Hamoun wetlands are located in the lower Helmand basin, an arid area between Iran and Afghanistan (Fig. 1). Because the Hamoun wetlands are affected by changes throughout the basin, it is not possible to study the wetlands as an isolated unit. The basin consists of three parts: (i) the delta of the Helmand (Hirmand) River in the upper basin, (ii) the wetlands (Hamoun) in the lower part of the delta, and (iii) a hypersaline lake (Gowd-e-Zareh) in the lowest part of the basin. In addition to the Helmand River, there are other smaller rivers in the basin. The Hamoun wetlands consist of three lakes: Hamoun-e Puzak, Hamoun-e Sabari, and Hamoun-e Helmand. The area of these three lakes is about 300000 ha during wet 

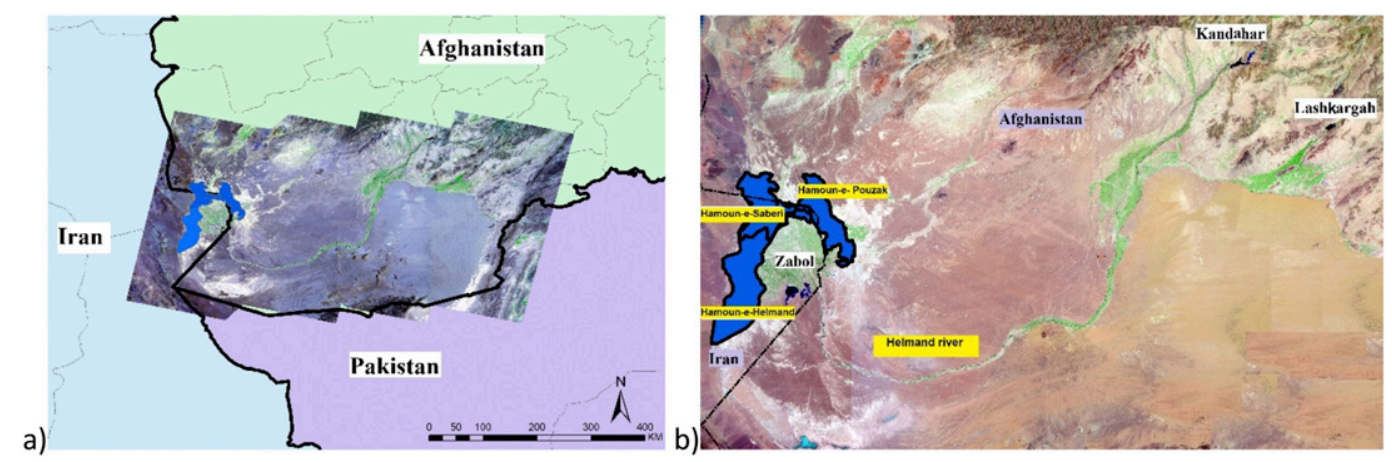

FIG. 1. (a) The lower Helmand basin showing (b) Zabol in Iran and Lashkargah and Kandahar in Afghanistan (major cities in the region). The Helmand is the main river feeding the Hamoun wetlands (Hamoun-e Puzak, Hamoun-e Sabari, and Hamoun-e Helmand).

conditions. The Iranian part of the Hamoun wetlands has been mentioned as a protected site in the Ramsar Convention (Ramsar 2016). The climate of this area based on the De Martonne method is arid (Maleki et al. 2016).

The Hamoun wetlands have a crucial role of supporting the life in the region because they are the only water source within a vast arid region. Furthermore, the Hamoun wetlands are also the only economic base due to a lack of any industry independent of water and the natural ecosystem in the region. Farming is the major occupation in this area and the Hamoun wetlands provide water for irrigation and other economic activities such as livestock grazing, reed-cutting, and fishing. Sustainable functioning and reliable services of the wetland ecosystems in this area are therefore the only sources of viable livelihoods in the region.

\section{b. Data sources}

Landsat Multi Spectral Scanner (MSS) images from 13 May 1977, Landsat Thematic Mapper images from 30 May 1991 and 10 May 2001, and Landsat Operational Land Imager (OLI) images from 13 May 2014 were used to assess the extent of LU-LC change over the past 37 years. The images were downloaded from the U.S. Geological Survey Earth Explorer portal (Table 1). In addition, satellites images from Google Earth (http://earth.google.com), digital elevation data from Shuttle Radar Topography Mission (SRTM), the Food and Agriculture Organization (FAO) project's land-use map of Afghanistan (FAO 2015), and data from field surveys within Iran were used as reference material for this study.

Long-term in situ meteorological data (precipitation and temperature) in Iran were used to examine changes in climate and variability in the study area. We could not find any meteorological data in Afghanistan to extend the climate data analysis to the Helmand basin. However, we used gridded data from the CRU (http:// www.cru.uea.ac.uk/data) to investigate the climate variability in the entire study area. Precipitation and mean monthly temperature were selected as climate variables for the data analysis.

For socioeconomic data, we included rural and urban population data, statistics on migration from rural to urban areas, and percent of unemployment in urban areas. These data were acquired from the Plan and Budget Organization (PBO) of Iran.

\section{FIELD INVENTORY}

To determine the characteristics of the study area and LU-LC classes, field inventories were done in the Iranian part of the study area. The field data were acquired using a stratified random sampling approach. Data for each LU-LC class included several ecological characteristics such as water depth, landscape type, vegetation height, and percent vegetation cover. All measurements included location data using the global positioning system (GPS).

TABLE 1. Data used in this study.

\begin{tabular}{|c|c|c|c|}
\hline Data & Resolution & & $\begin{array}{c}\text { Dates of images/ } \\
\text { data used }\end{array}$ \\
\hline MSS & $60 \mathrm{~m}$ & 7 scenes & 13 May 1977 \\
\hline Landsat-5 & $30 \mathrm{~m}$ & 7 scenes & 30 May 1991 \\
\hline Landsat-7 & $30 \mathrm{~m}$ & 7 scenes & 10 May 2001 \\
\hline Landsat-8-OLI & $30 \mathrm{~m}$ & 7 scenes & 13 May 2014 \\
\hline $\begin{array}{c}\text { FAO project's land-use } \\
\text { map of Afghanistan }\end{array}$ & & & 2015 \\
\hline Topographic map & $1: 50000$ & & 1986 and 2004 \\
\hline $\begin{array}{l}\text { Digital elevation data } \\
\text { from SRTM }\end{array}$ & & & \\
\hline Google Earth & $\begin{array}{l}\text { Varying } \\
\text { resolution }\end{array}$ & & 2014,2015 \\
\hline Ground observation & & & $\begin{array}{l}\text { May-August } \\
2014\end{array}$ \\
\hline
\end{tabular}


TABLE 2. Spectral indices used in conjunction with Landsat spectral bands and tasseled cap brightness (TCB), greenness (TCG), and wetness (TCW).

\begin{tabular}{lll}
\hline \hline Spectral index & \multicolumn{1}{c}{ Formula } & \multicolumn{1}{c}{ Reference } \\
\hline TCWGD & TCW - TCG & Huang et al. (2014) \\
NDVI & (band 4 - band 3) $/($ band $4+$ band 3) & Chander and Helder (2009) \\
NDVI-1 & (band 4 - band 5)/(band 4 + band 5) & Agapiou et al. (2011) \\
NDVI-2 & (band 3 - band 5)/(band 3 + band 5) & Sexton et al. (2013) \\
TCA & Arctan $($ TCG/TCB) & Wang et al. (2009) \\
IVR & band 5/band 2 & Theobald (2001) \\
IR & (band 5 - band 7)/(band 5 + band 7) & Ruan et al. (2007) \\
\hline
\end{tabular}

\section{c. Methods}

In this study, we rely extensively on global gridded meteorological and remotely sensed data to determine the changes in the study area.

\section{1) Climate data Processing}

The station weather data in Afghanistan are not complete over the study period (1977-2014), thus global weather gridded data were used. To select the most accurate gridded data, the gridded climate data of Zabol were compared against the weather station data provided by the Iran Meteorological Organization. Finally, CRU data were selected because they have the highest correlation with observed data.

We used the Mann-Kendall (MK) test to determine the trend in the selected variables from the CRU data. The MK test is not sensitive to outliers in the data and can detect monotonic linear and nonlinear time series trends without making any assumptions that the data are distributed normally or that the trend is linear (Zhao et al. 2016). The trend is determined using the equation:

$$
S=\sum_{i=2}^{n} \sum_{j=1}^{j-1} \operatorname{sign}\left(x_{i}-x_{j}\right)
$$

where $x_{i}$ and $x_{j}$ are the sequential data values, $n$ is the length of the time series, and the sign $\left(x_{i}-x_{j}\right)$ is an indicator function that takes on the values of $-1,0$, and 1 according to the sign of $\left(x_{i}-x_{j}\right)$. That is, sign $\left(x_{i}-x_{j}\right)$ is equal to -1 for $\left(x_{i}-x_{j}\right)<0$, equal to 0 for $\left(x_{i}-x_{j}\right)=0$, and equal to 1 for $\left(x_{i}-x_{j}\right)>0$. The variance of $S$ $(\operatorname{Var}[S])$ is calculated by the following equation:

$\operatorname{Var}[S]=\frac{n(n-1)(2 n+5)-\sum_{p=1}^{q} t p(t p-1)(2 t p+5)}{18}$,

where $t p$ is the number of observations the for the $p$ th group and $q$ is the number of tied groups.
The standardized test statistic (ZMK) is calculated using Eq. (3):

$$
\mathrm{ZMK}= \begin{cases}\frac{S-1}{\sqrt{\operatorname{Var}[S]}} & \text { if } S>0 \\ 0 & \text { if } S=0 \\ \frac{S+1}{\sqrt{\operatorname{Var}[S]}} & \text { if } S<0 .\end{cases}
$$

A positive $\mathrm{ZMK}$ means an increasing trend, and a negative ZMK means a decreasing trend. Usually, confidence levels of $99 \%, 95 \%$, and $90 \%$ signify the positive or negative trends determined by the test statistic. The MK test will determine whether to reject the null hypothesis of no monotonic trend and accept the alternative hypothesis of the presence of a monotonic trend at different confidence intervals (CI). For example, the null hypothesis is rejected when $|Z|>2.575$ at $99 \% \mathrm{CI}$, when $|Z|>$ 1.96 at the $95 \% \mathrm{CI}$, and when $|Z|>1.645$ at the $90 \%$ CI (Hossain et al. 2014). We used the sequential MK (SQMK) test is used in order to detect the trend over a study period and to determine the beginning of this trend. The sequential values, $u(t)$ and $u^{\prime}(t)$, are calculated using the progressive analysis of the MK test. We assume $u(t)$ has zero mean and unit standard deviation as a standardized variable and $u(t)$ and $u^{\prime}(t)$ are computed using Eq. (4):

$$
u(t)=\frac{t j-E(t)}{\sqrt{\operatorname{Var}(t j)}}
$$

where

$$
t j=\sum_{1}^{j} n j,
$$

$n=$ years of time series,

$$
E(t)=\frac{n(n-1)}{4},
$$




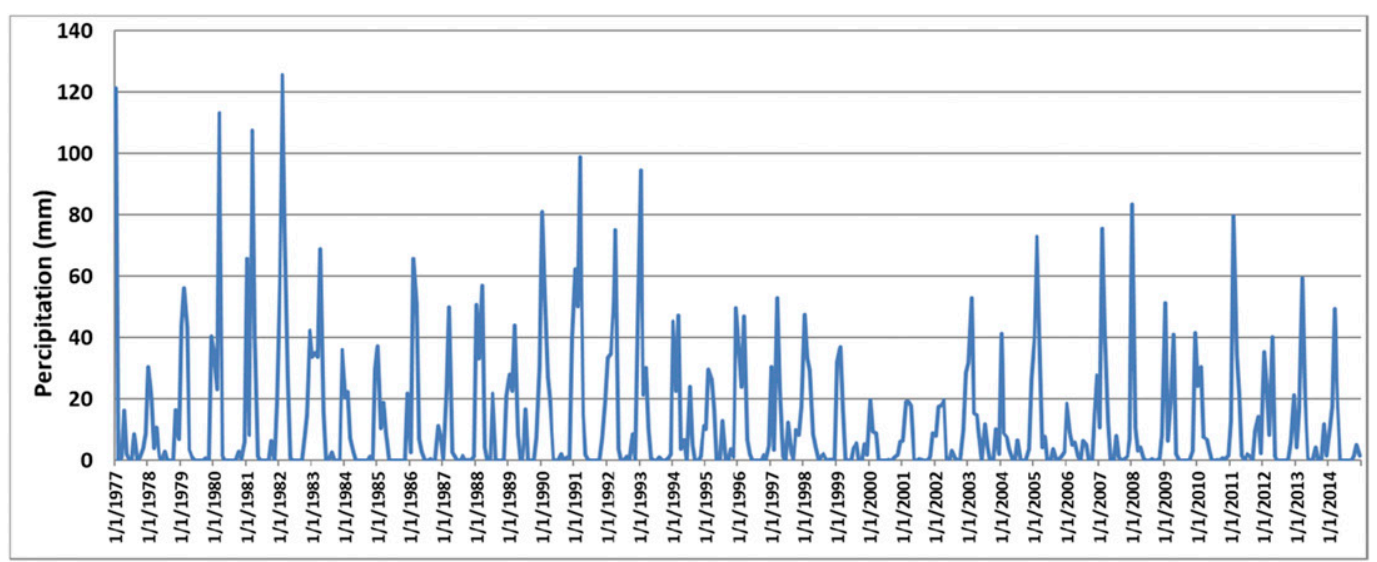

Kandahar precipitation

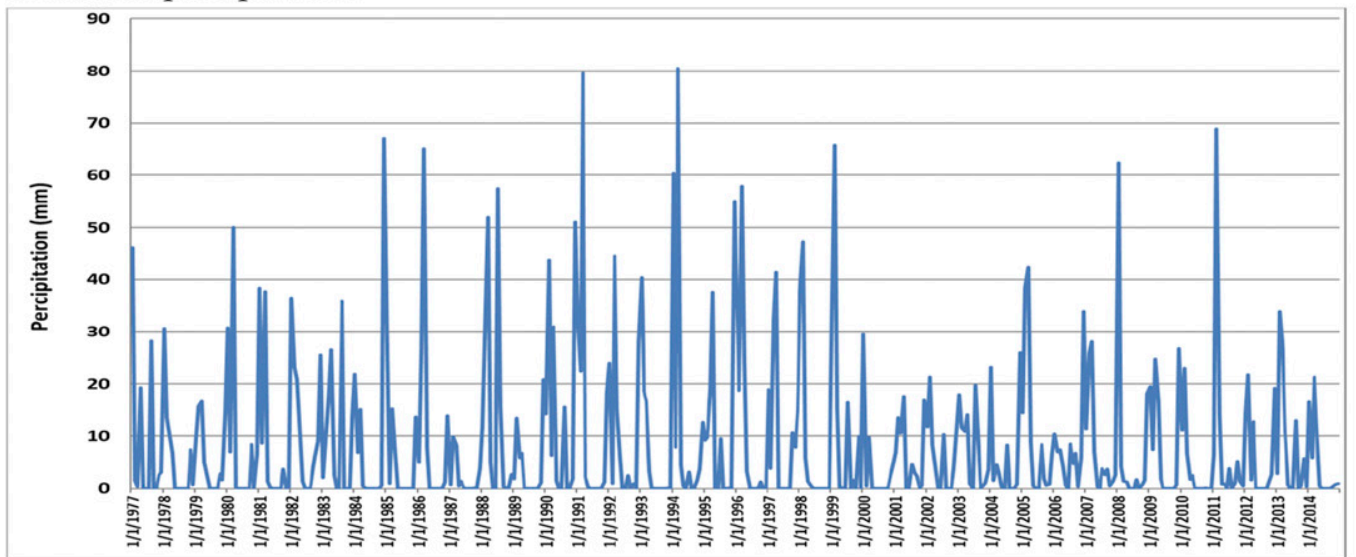

Lashkargah precipitation

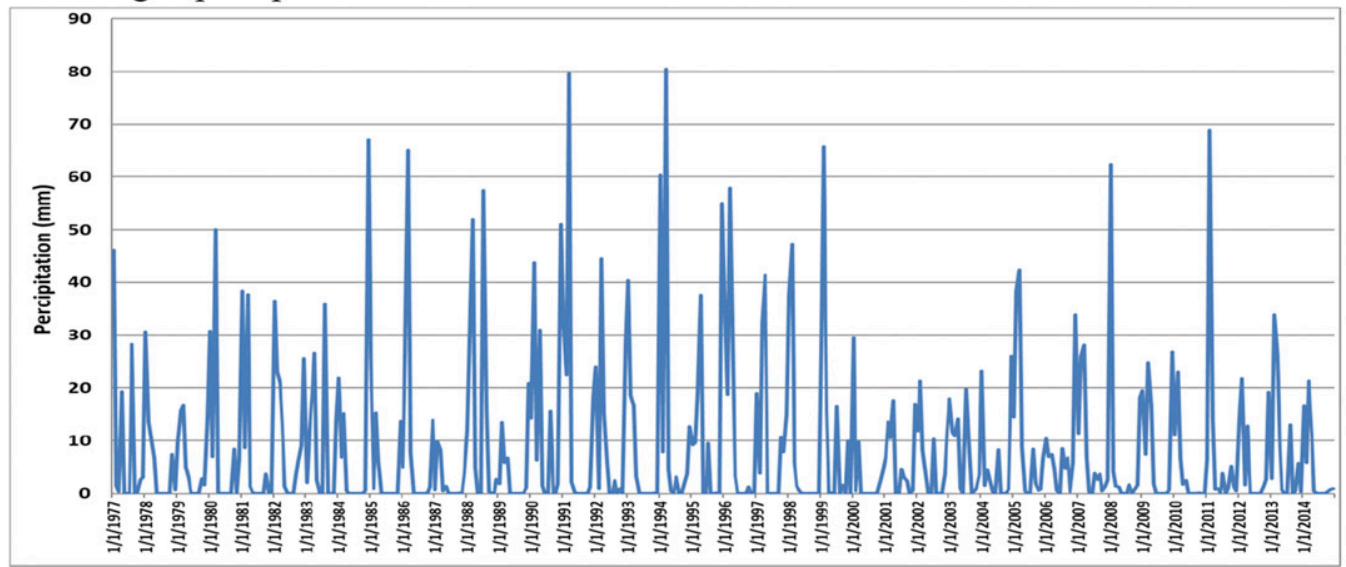

Zabol precipitation

FIG. 2. CRU monthly and annual precipitation variation in Kandahar, Lashkargah, and Zabol (1977-2014).

$$
\operatorname{Var}(t j)=[j(j-1)(2 j+5)] / 72,
$$

$E(t)=$ mean and $\operatorname{Var}(t j)=$ variance of the test statistic.

The $u^{\prime}(t)$ is calculated the same as $u(t)$ but starting from the end of the series. In this study, the MK test was used to detect the change in the annual precipitation, and the mean annual temperature in three major locations (stations) in the study area: Kandahar, Lashkargah, and Zabol.

In the MK test, the magnitude of slope is used to investigate the tendency of parameters. A positive 

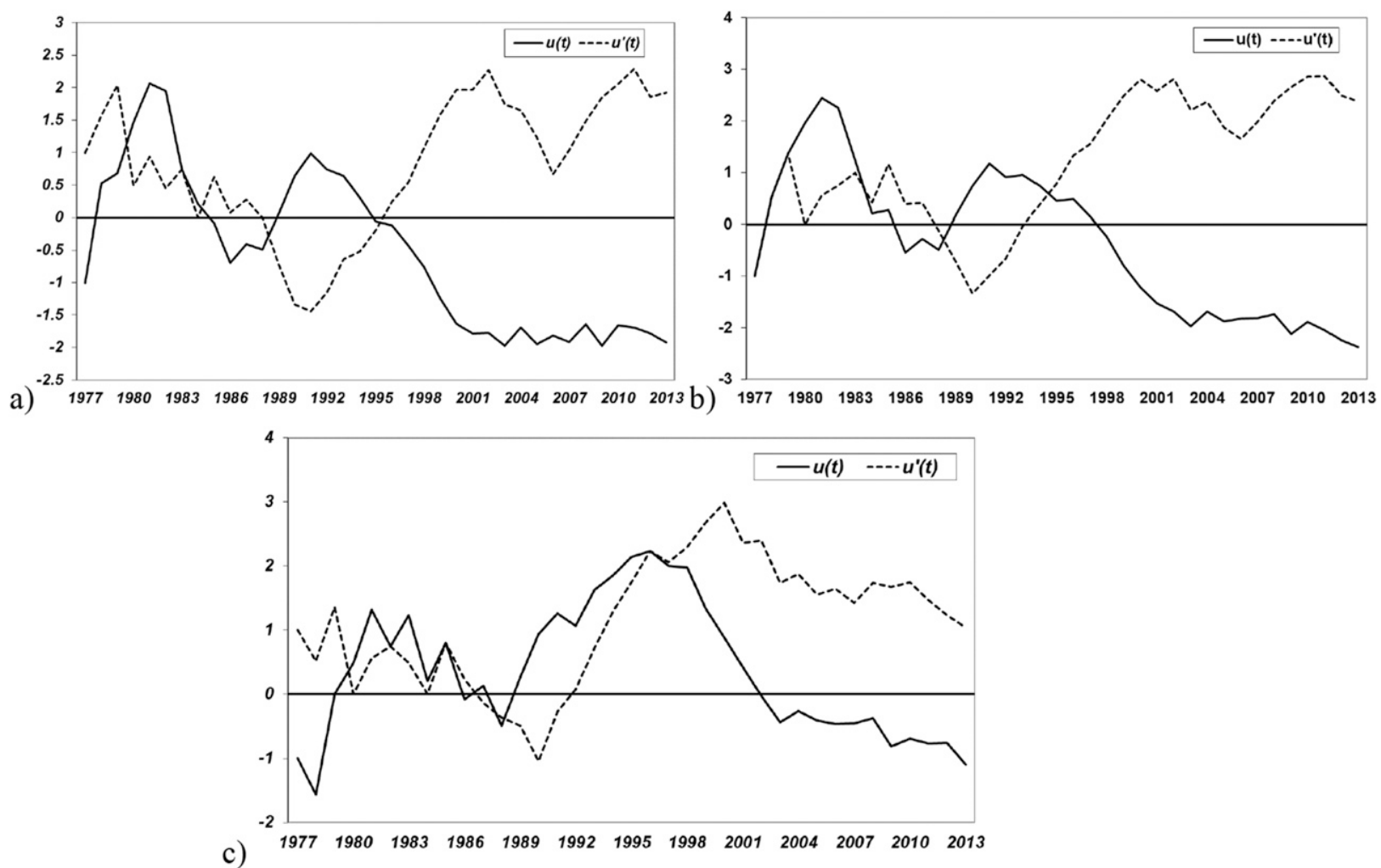

FIG. 3. Sequential values of the statistics $u(t)$ (solid line) and $u^{\prime}(t)$ (dashed line) from the MK test of annual precipitation for (a) Kandahar station, (b) Lashkargah station, and (c) Zabol station; $u(t)$ indicates a forward trend and $u^{\prime}(t)$ is backward trend.

slope magnitude indicates an increasing trend, while a negative slope magnitude indicates a decreasing trend (Zhao et al. 2016). To determine the intensity and duration of drought in the study area, annual precipitation and mean annual temperature anomalies of 1977-2014 were calculated using monthly time series of CRU data at $0.5^{\circ}$ grid cells. Equation (5) was applied to calculate the standard anomaly for each year:

$$
P_{\text {Anomaly }}(i, j)=\frac{P y(i, j)-[\mathrm{P} 1977-2014(i, j)]}{\mathrm{STD}[\mathrm{P} 1977-2014(i, j)]}
$$

$$
\begin{aligned}
\text { P1977-2014 } & =1977 \text { Mean }-2014 \text { Mean }, \\
P y & =\text { measurement from year }(y), \\
\text { STD } & =\text { standard deviation } .
\end{aligned}
$$

\section{2) Changes in human activities}

\section{(i) LU-LC map}

LU-LC classes were selected based on previous studies (FAO 2015; Maleki et al. 2016; Shamohammadi and Maleki 2011) and field observations in Iran. Supervised classification and spectral indices were applied to develop the map of LU-LC classes. The vegetation classes were created using infrared ratio (IR), soil-adjusted vegetation index (SAVI), normalized difference vegetation index (NDVI), and tasseled cap transformation (TASSCAP) (Table 2). These indices were examined against field measurements and the NDVI was selected to produce vegetation classes. To discriminate natural vegetation from agriculture, we used high-resolution satellite data from Google Earth and other ancillary data outlined earlier.

The water class was separated from other land cover types by using the normalized difference water index (NDWI), the NDVI index, and the tasseled cap wetness-greenness difference index (TCWGD), to which a principal component analysis (PCA) was applied (Table 2). Comparison between the satellitederived vegetation indices and field observations showed that TCWGD outperformed other indices to separate the water classes. We used TCWGD to classify the water for all dates of satellite imagery. Finally, the results of indices and supervised classification were compared with field samples and the most accurate classes were overlaid to compile an 

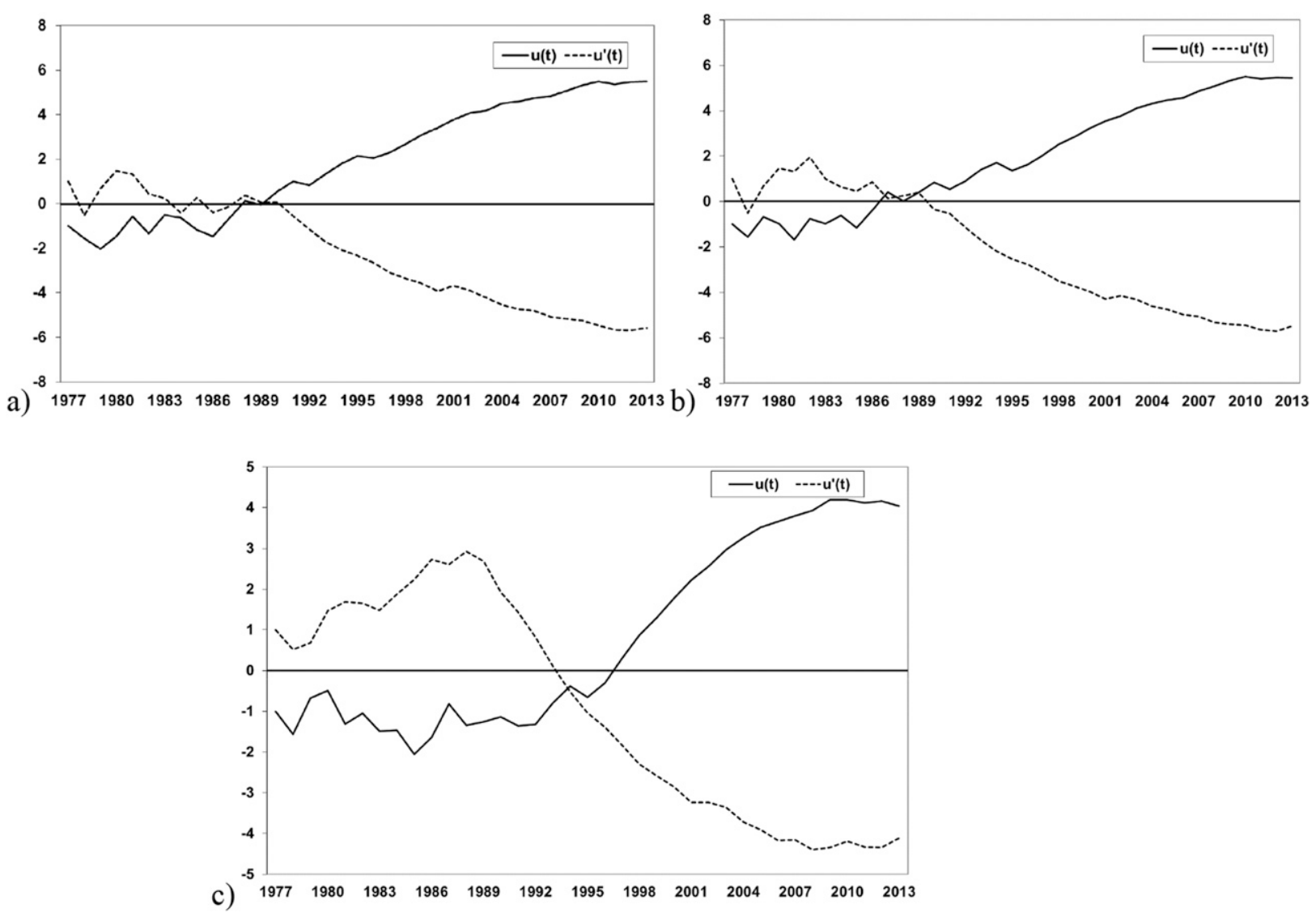

FIG. 4. Sequential values of the statistics $u(t)$ (solid line) and $u^{\prime}(t)$ (dashed line) from the MK test for mean annual temperature for

(a) Kandahar station, (b) Lashkargah station, and (c) Zabol station; $u(t)$ indicates a forward trend and $u^{\prime}(t)$ is backward trend.

LU-LC map for the study area and for all selected time periods.

(ii) LU-LC accuracy assessment Accuracy assessment was performed on each map using a number of validation points relative to the number of pixels in each class based on the stratified random approach in the field data collection. Visual interpretation, field measurements, and the reference material (section 2b) were used to label these test pixels. The 1977 and 1991 classified Landsat images were compared with the 1986 topographic maps. Google Earth and other reference materials were applied for 2001 and 2014 and the kappa coefficient $(\kappa)$ was calculated for the validation of all maps.

\section{3) SOCIOECONOMIC VARIATION IN DOWNSTREAM}

The LU-LC maps were used to estimate the changes across all classes over the period of the study (19772014). The results of LU-LC change were divided into two parts for the downstream and upstream areas of the lower Helmand basin. These results showed that the downstream region is impacted by the intensifying water limitation more than upstream areas and that agriculture is relatively less developed. These changes suggest that the downstream areas will experience more socioeconomic hardship than the upstream from any changes from climate and ecosystem degradation. To investigate the effects of these conditions in the downstream areas, the percent of rural and urban population, migration from rural to urban areas, and unemployment data in urban areas were used.

\section{Results and discussion}

\section{a. Climate variation}

Comparison between the CRU data for Zabol and the weather station data provided by the Iran Meteorological Organization confirmed the accuracy of CRU data to use as the real data. The high correlation (Pearson's $R=0.71$ ) indicates that CRU monthly precipitation can represent real precipitation with acceptable accuracy and does not need any calibration. Pearson's $R=0.78$ for mean annual temperature confirms this for mean annual temperature as well. 

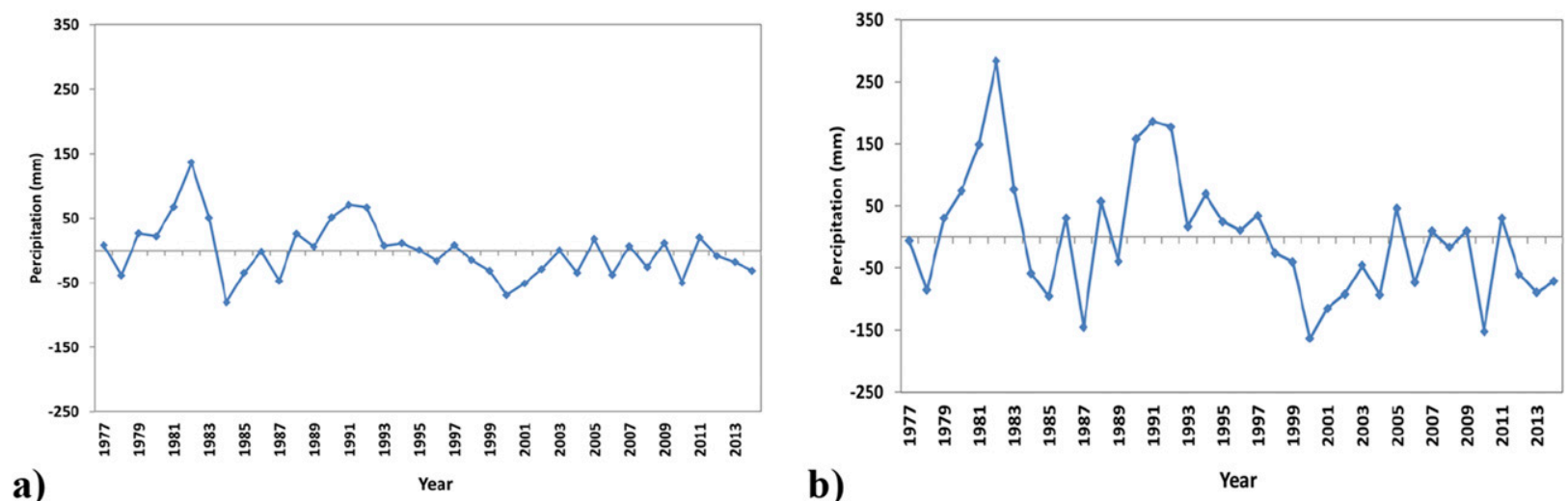

a)

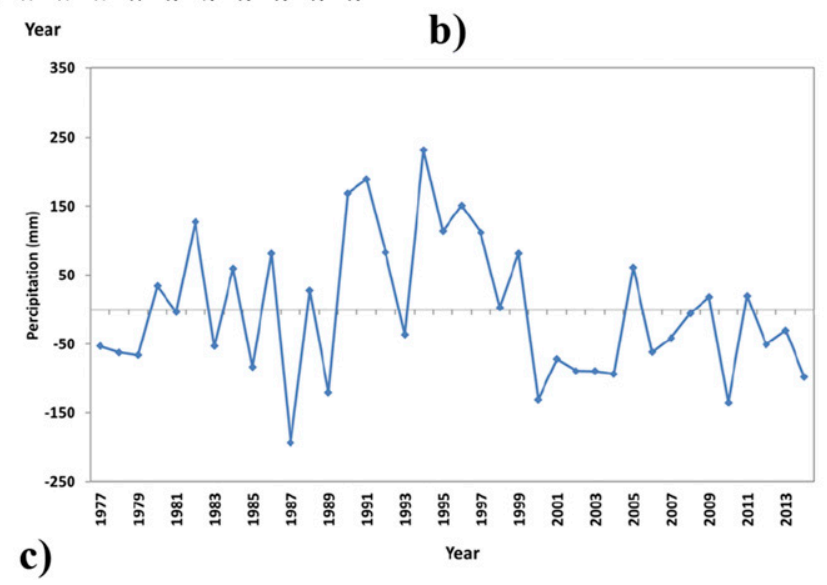

FIG. 5. Precipitation anomalies for (a) Kandahar, (b) Lashkargah, and (c) Zabol.

The short-term analysis of precipitation patterns may be affected by an overestimation (Saatchi et al. 2013), therefore we selected a longer time series using the CRU monthly precipitation dataset from 1977 to 2014. The monthly and the annual precipitation variation in Kandahar, Lashkargah, and Zabol (1977-2014) are illustrated in Fig. 2.

The results of MK test show a decreasing trend in precipitation $\left(Z_{\text {Zaol,Lasgargah,Kandahar }}=-1.98,-2,-1.96\right.$, $p<0.05)$ and an increasing trend in annual mean temperature $\left(Z_{\text {Zaol,Lasgargah,Kandahar }}=+1.97,+1.98,1.98\right.$, $p<0.05)$.

Sequential values of the statistics $u(t)$ (solid line) and $u^{\prime}(t)$ (dashed line) from the MK test of annual precipitation for Kandahar, Lashkargah, and Zabol are presented in Fig. 3. As the plot of $u(t)$ indicates, there was an increasing trend in precipitation in the 1980s. After that, a decreasing trend began in the 1990s and has continued to the present.

On the other hand, the results of MK test for mean annual temperature (Fig. 4) show an increasing trend began in the 1990s.

Similar behavior in sequential values is observed for all three stations. It demonstrates that the decreasing trend in precipitation and the increasing trend in mean annual temperature in this region began in the 1990s.

The precipitation anomaly (Fig. 5) confirms an increase in precipitation at the three stations in the late 1980s. It also verifies a reduction in precipitation in the 1990s. On the other hand, the mean annual temperature anomaly (Fig. 6) confirms that the climate of the study area is getting warmer.

Thus, the results of the climate variability analysis showed the climate of the lower Helmand basin is getting warmer and drier. These changes reinforce the region's water limitation because the only water input in this basin is precipitation. Now the question is, do human activities mitigate or exacerbate the effect of this limitation?

\section{b. Land-use change in the Lower Helmand basin}

To recognize LU-LC change in the lower Helmand basin, LU-LC maps for 13 May 1977, 30 May 1991, 10 May 2001, and 13 May 2014 were created. The overall accuracy for LU-LC maps for each year is $84.2 \%, 85.1 \%$, $86.3 \%$, and $90 \%$ for $1977,1991,2001$, and 2014 , respectively. The results of accuracy assessment for all LU-LC maps show the acceptable classification of these maps (Lu and Weng 2009; Dong et al. 2014). 

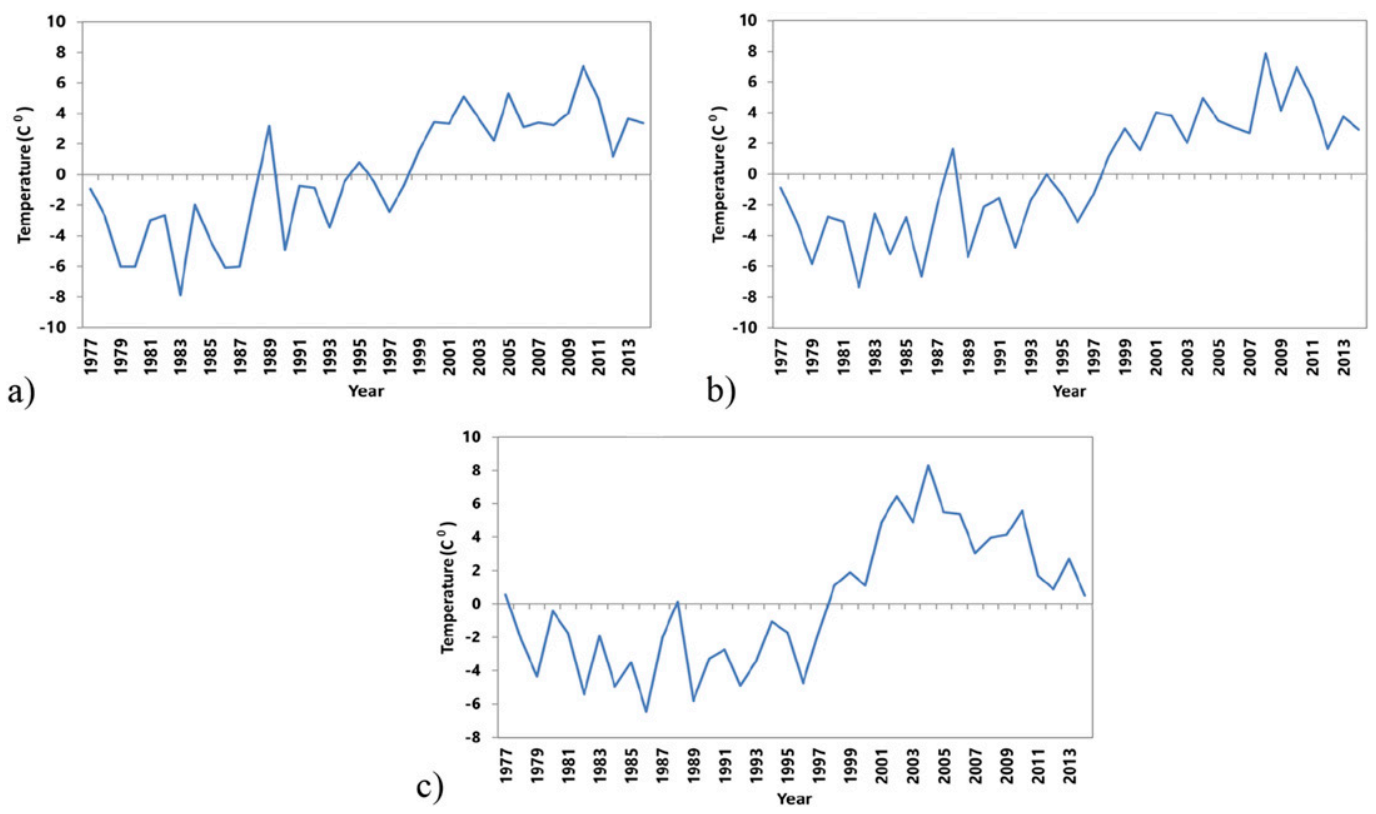

FIG. 6. Mean annual temperature anomalies for (a)Kandahar, (b) Lashkargah, and (c) Zabol.

The LU-LC maps for 13 May 1977, 30 May 1991, 10 May 2001, and 13 May 2014 are presented in Fig. 7. The areas of LU-LC classes for each date were calculated and are presented in Table 3. Figure 8 was created based on Table 3. This figure shows the area of the most important LU-LC classes in the study period. These classes are water surface, marsh and mudflats, and agriculture. As this figure shows, agriculture developed over this period in the lower Helmand basin. As seen, water area increased between 1977 and 1991 but after that the area of this class reduced from 390158 to 23516 ha between 1991 and 2001. Based on Fig. 7c, the a)

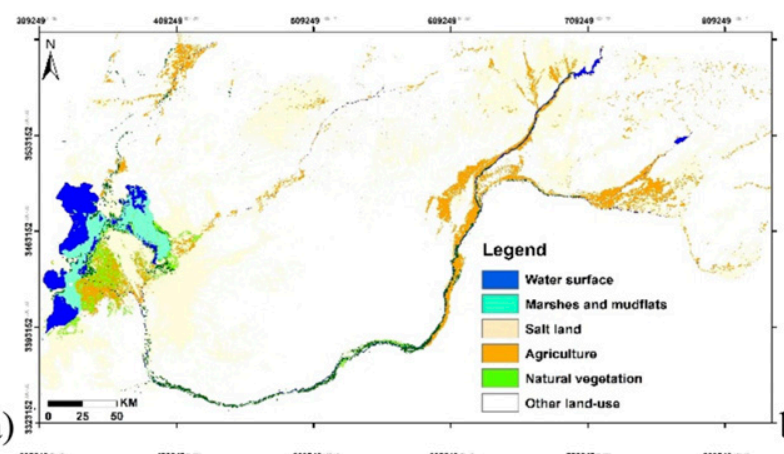

c)

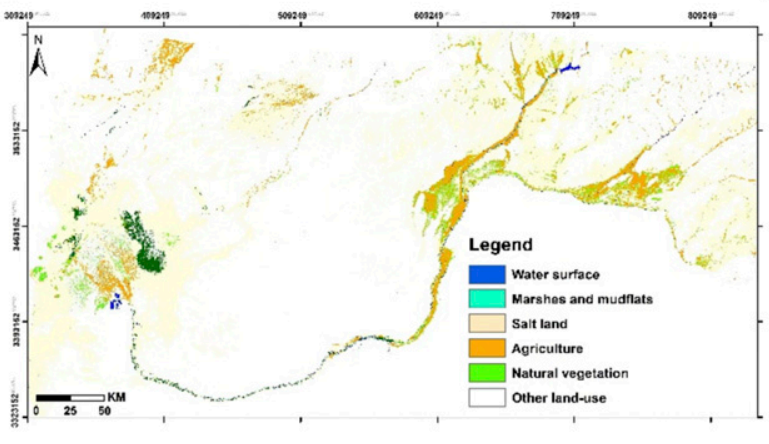

b)

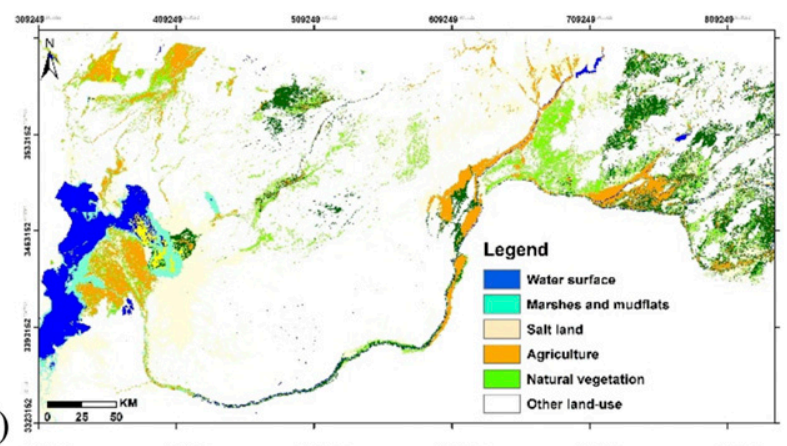

d)

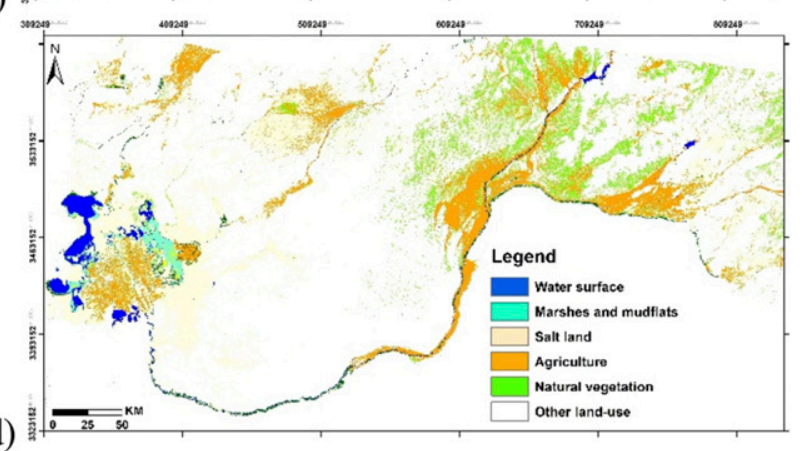

FIG. 7. The lower Helmand basin land use/land cover (a) 1977, (b) 1991, (c) 2001, and (d) 2014. 
TABLE 3. Area of land-use classes (ha).

\begin{tabular}{lccccr}
\hline \hline $\begin{array}{c}\text { Land-use/ } \\
\text { land-cover class }\end{array}$ & Code & 1977 & 1991 & 2001 & \multicolumn{1}{c}{2014} \\
\hline $\begin{array}{l}\text { Water surface } \\
\text { Marshes and }\end{array}$ & 1 & 207569 & 390158 & 23516 & 134969 \\
$\quad$ mudflats & 2 & 150332 & 199472 & 3 & 89632 \\
$\quad \begin{array}{l}\text { Salt land } \\
\text { Agriculture }\end{array}$ & 3 & 1687050 & 949400 & 2455080 & 1275630 \\
$\quad$ Natural & 4 & 436704 & 576277 & 374129 & 868420 \\
$\quad$ vegetation & 5 & 195359 & 1176278 & 240153 & 702290 \\
\hline
\end{tabular}

Hamoun wetlands were completely dry in 2001. Thus, the area of water surface in that year reflects the lakes behind dams. Although decreasing precipitation accounts for some of the loss of water, the impoundment of water in dams in the upstream region of the basin has strengthened the effect of decreasing precipitation on the Hamoun wetlands.

In 2014, the area of water surface was 134969 ha, but comparison between 1977, 1991, and 2014 shows that the area of water was reduced in the study period. This finding reveals the extent of water limitation in the study area.

During the study period, the water areas were reduced by $60 \%$ and marsh areas by $40 \%$, whereas the agricultural area doubled. This means, alongside the reduction in natural cover classes such as water and marsh, artificial land use (agriculture) expanded. It confirms that there is negative pressure on natural ecosystem in this area. Although water resources decreased in this region, agriculture expanded, placing greater strain on decreasing resources. According to the FAO Technical Cooperation Programme (TCP; FAO 2015), agriculture land use is the most water-consuming class in the region.

These results not only confirm water limitation in the lower Helmand basin, but also show the negative pressure exerted on the ecosystem by expanding agriculture. Furthermore, the reservation of water in the upstream dams exacerbates water limitation in the downstream region.

To compare the changes in the upstream and downstream regions, the LU-LC maps were divided into two parts. The area of three major LU-LC classes (water surface, agriculture, marsh, and mudflats) were calculated for each part. The area of these three classes is presented in Fig. 9. Based on this figure, in 1977 and 1991, the water body area in the downstream region is higher than in the upstream region, which is logical in a catchment basin. But in 2001 and 2014, this pattern was reversed. Changes in the marsh area follow the same pattern as the water changes. The agriculture area is higher in upstream in all years, but despite the water limitation, agriculture was developed intensively there through 2014 while agriculture remained low in downstream region. Both water reduction by climate variation

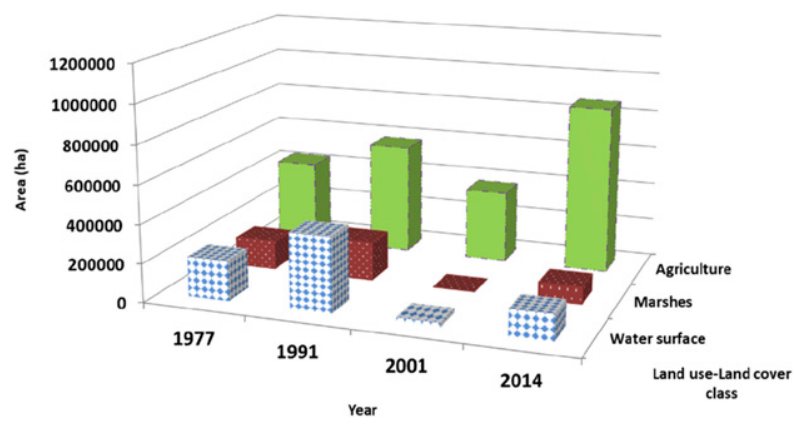

FIG. 8. Temporal changes for three major land-cover classes from 1977 to 2014.

and water reservation by dams are negatively affecting the downstream ecosystem. Now the question is, how do socioeconomic parameters respond to these effects?

\section{c. Socio-economic variation in down stream}

The results of LU-LC change in section $3 b$ showed that the downstream region is dealing with more intense water limitation than the upstream region. Thus, these changes can lead to greater socioeconomic difficulties in the downstream region. To investigate the socioeconomic condition downstream, the rural and urban population percent (Fig. 10), migration from rural to urban areas and unemployment percent in urban areas were used.

As Fig. 10 shows, the population percent of rural areas were declined between 1956 and 2011. During the first 30 years (1956-86), the rural population decreased $10 \%$, but in the last 25 years (1986-2011), the decline was close to $40 \%$. Majdabadi 2007 mentioned since industry was not developed in this region, agriculture and fisheries are the major occupations, and so changes in the proportions of rural and urban population are due to changes in natural resources. The migration change rate has the same pattern as the rural and urban population percent. The Migration from rural to urban areas in 1981, 1996, 2006, and 2011 was $10 \%, 15 \%, 34 \%$, and $37 \%$ respectively. Based on these two indices, it seems the rural areas are being abandoned. On the other hand, unemployment percent in urban areas increased. While the unemployment percent in 1986 and 1996 was 5\%, it reached to $30 \%$ in 2011 . These three indices show in the downstream region of the lower Helmand basin, socioeconomic conditions are becoming worse. The rural areas which are the source of agricultural production being abandoned and the population of cites that consume these products are rising. Also, the cities are dealing with the problem of immigration from rural areas and high unemployment. Because the income of people in the lower Helmand basin is largely dependent 

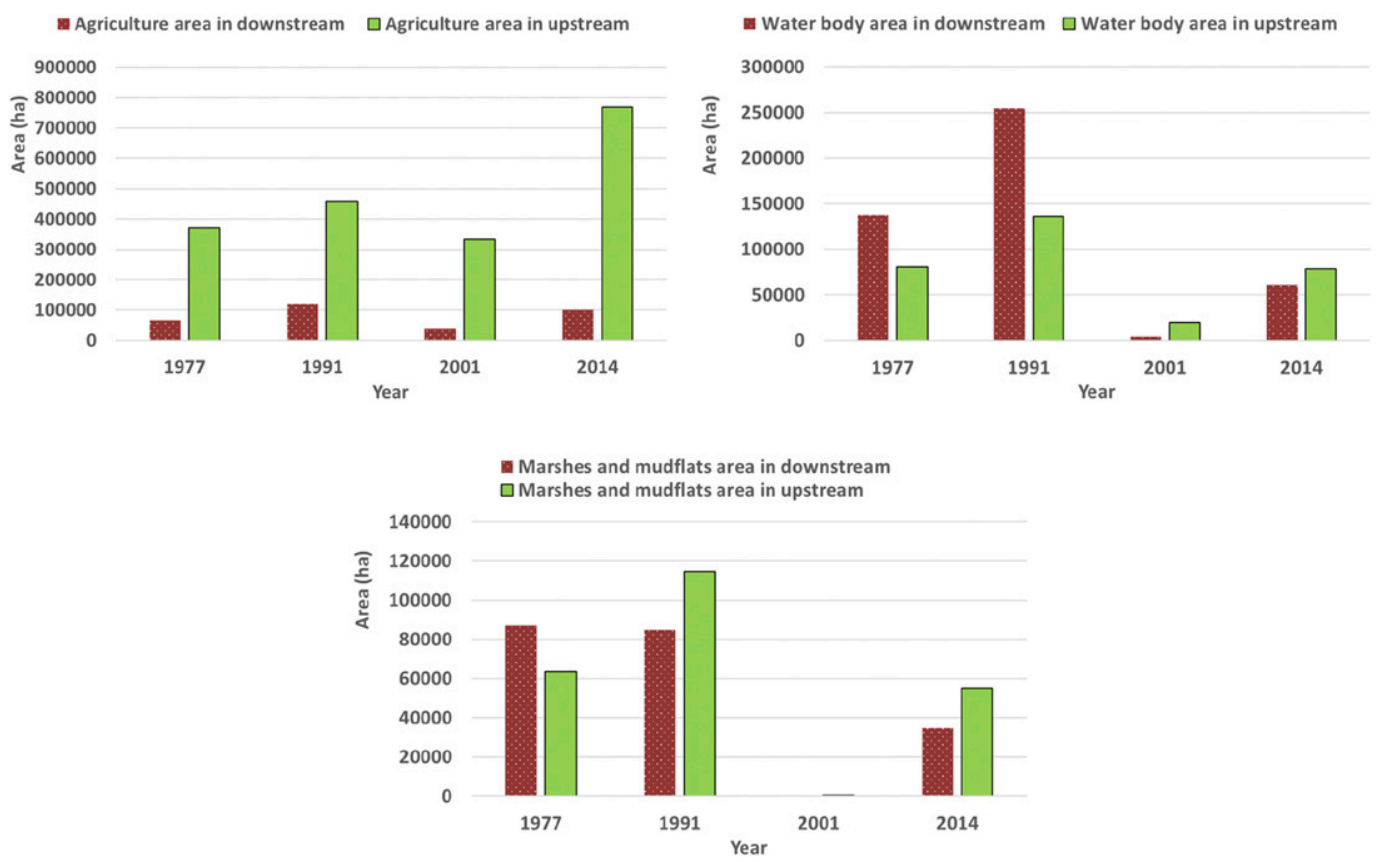

FIG. 9. Area of three major land-use/land-cover classes in the upstream and downstream regions of the lower Helmand basin.

on the health of the wetland ecosystem and the availability of water, water limitation will produce difficulties in the region (Sajadi et al. 2014).

\section{d. Human and climate variation effects on the Hamoun wetlands}

The results of the climate analysis showed that the climate is getting drier and warmer in the lower Helmand basin. This change leaded to decrease water input from precipitation. The results of LU-LC confirmed that the water surface decreased from 1977 to 2014. These two results confirmed the effects of climate change in the region. On the other hand, humans have exacerbated the negative effects of climate change by impounding the river's water behind dams in the upstream region and developing unsustainable agriculture throughout the basin. In brief, climate-caused drought and human activity has intensified its effects, creating a socioeconomic crisis in this region.

Since the Hamoun wetlands are important water resources in an arid area and the lives of human and animals dependent on them (Maleki et al. 2018), it is essential to develop a sustainable plan for human activities to mitigate the negative effects of climate variability in this area. The importance of such a plan has been suggested by researchers in other areas experiencing negative impacts of human activity combined with climate change, such as upper Thames River basin in Canada (Eum et al. 2012), northwestern
China (Zhao et al. 2016), central Asia's arid regions (Fu et al. 2017), and Bangladesh (Hossain et al. 2016).

\section{e. Application of human and climate change}

In recent decades, many efforts have been made to reduce the negative effects of climate change on human communities. The IPCC's Synthesis Report of Climate Change 2001 confirmed that most of the warming observed over the last 50 years is related to human activities (IPCC 2001). As many international scientific organizations have emphasized in their reports, specific policies have important roles in developing an effective response to climate change (Scheraga et al. 2003; National Research Council 2010). Investigating the trend and combination of climate variability and human activity

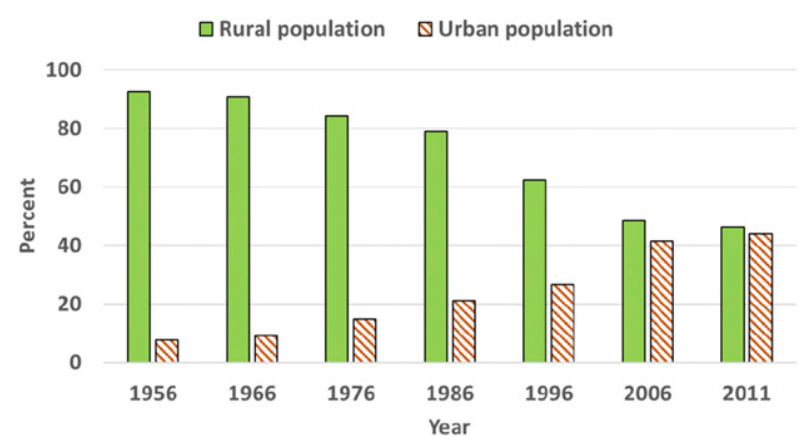

FIG. 10. Rural and urban population trends in the downstream region of the lower Helmand basin. 
is a useful tool for evaluating policies and getting a better understanding of the situation.

Some studies have investigated trends of human activity and climate variability separately (Loveland and Defries 2004; Chen et al. 2006; Elshamy et al. 2009; Elsanabary and Gan 2015; Fu and Weng 2016), but the study of coupled human and climate effects considers both terms. When the climate gets both drier and warmer in an area, land-use policies can mitigate or exacerbate the negative effects of climate change on local communities and natural ecosystems. For instance, in the lower Helmand basin, despite the reducing trend in precipitation in recent years, the agriculture which is the largest water consumer in this area (FAO 2015) has been further developed, and water has been impounded behind dams upstream. These actions have exacerbated the negative effects of drought on the Hamoun wetlands. As a result of reduced water in the wetland, rural areas in the region have been abandoned and cities are facing the twin problem of increased immigration from rural areas and high unemployment.

To mitigate the negative effects of drought in this area, changes in cropping patterns and optimization of irrigation and land-use planning are the most important activities. These scenarios are also suggested by previous studies (e.g., El-Khoury et al. 2015; van der Pol et al. 2015; Langerwisch et al. 2018; Scullion et al. 2014). Zimmerman and Faris (2011) introduced landuse planning as an important adaptation action plan for North America for adaptation to climate change, and Carter (2011) mentioned LU-LC planning as an adaptation policy against climate change in European cities, suggesting the promise of such an approach.

\section{Conclusions}

In this study, climate variability and land-use change over 37 years (1977-2014) in the lower Helmand basin were investigated to assess the coupled effects of human and climate change in this region.

Land-cover maps across the lower Helmand basin were produced. Remote sensing provides a cost-effective data source for mapping different phenomena across a large area. Moreover, the rich archive of Landsat images provides a valuable resource of data over a long temporal period.

For climate analysis, because there is not a complete, long-term, spatially distributed, and reliable climate dataset in Afghanistan, CRU data were used. For this purpose, precipitation and mean annual temperature data produced by CRU were compared against the gauge data that were provided by the Iran Meteorological Organization. This comparison showed that the CRU data were able to capture patterns of climate variability in the study area. An MK test of precipitation and mean annual temperature over the lower Helmand basin showed a significant trend in both variables. In summary, after an increasing trend in precipitation through the $1980 \mathrm{~s}$, mean annual precipitation decreased in the 1990 s, while mean annual temperature increased over the same period. These trends indicate that the climate is getting drier and warmer in the lower Helmand basin. Thus climate variation has increased the water limitation in the basin. Also, the results of LU-LC change detection illustrated that the water surface decreased from 1977 to the present, confirming the region's water limitation. Based on the LU-LC maps, human activity has exacerbated the negative effects of climate change by dams and unsustainable agriculture. Climate caused the drought, and human activity is intensifying its effects. These two factors have dried out the Hamoun wetlands, leading to socioeconomic crisis in the downstream region of the lower Helmand basin.

Human activities and unsustainable policies can exacerbate climate change stress on ecosystem. Policies that take into account the combined effects of human activity and climate change, on the other hand, can make a strong contribution to developing an effective response to climate change.

\section{REFERENCES}

Agapiou, A., D. G. Hadjimitsis, C. Papoutsa, D. Alexakis, and G. Papadavid, 2011: The importance of accounting for atmospheric effects in the application of NDVI and interpretation of satellite imagery supporting. Remote Sens., 3, 2605-2629, https://doi.org/10.3390/rs3122605.

Barrios, S., B. Ouattara, and E. Strobl, 2008: The impact of climatic change on agricultural production: Is it different for Africa? Food Policy, 33, 287-298, https://doi.org/10.1016/ j.foodpol.2008.01.003.

Behrouzi-rad B., 2009: Waterbird populations during dry and wet years in the Hamoun Wetlands Complex, Iran/Afghanistan Border. Podoces, 4 (2), 88-99.

Bortels, L., J. Chan, R. Merken, and N. Koedam, 2011: Long-term monitoring of wetlands along the Western-Greek Bird Migration Route using Landsat and ASTER satellite images: Amvrakikos Gulf (Greece). J. Nat. Conserv., 19, 215-223, https://doi.org/10.1016/j.jnc.2011.01.004.

Carter, J. G., 2011: Climate change adaptation in European cities. Curr. Opinion Environ. Sustainability, 3, 193-198, https://doi.org/ 10.1016/j.cosust.2010.12.015.

Chander, G., and D. L. Helder, 2009: Summary of current radiometric calibration coefficients for Landsat MSS, TM, ETM+, and EO-1 ALI sensors. Remote Sens. Environ., 113, 893-903, https://doi.org/10.1016/j.rse.2009.01.007.

Chen, X., H. Zhao, P. Li, and Z. Yin, 2006: Remote sensing imagebased analysis of the relationship between urban heat island and land use/cover changes. Remote Sens. Environ., 104, 133146, https://doi.org/10.1016/j.rse.2005.11.016. 
Dahmardeh, M., M. Dahmardeh, S. Yazdani, and E. Piri, 2009: The socio-economic effects of Hamoon Lake in Sistan region of Iran. J. Food Agric. Environ., 7 (2), 799-802.

Dai, A., 2013: Increasing drought under global warming in observations and models. Nat. Climate Change, 3, 52-58, https:// doi.org/10.1038/nclimate1633.

Dong, Z., Z. Wang, D. Liu, K. Song, C. Ren, and M. Jia, 2014: Spatial decision analysis on wetlands restoration in the lower reaches of Songhua River (LRSR) in northeast China, based on remote sensing and GIS. Int. J. Environ. Res., 8, 849-860.

El-Khoury, A., O. Seidou, D. Lapen, Z. Que, M. Mohammadian, M. Sunohara, and D. Bahram, 2015: Combined impacts of future climate and land use changes on discharge, nitrogen and phosphorus loads for a Canadian river basin. J. Environ. Manage., 151, 76-86, https://doi.org/10.1016/j.jenvman.2014.12.012.

Elsanabary, M., and T. Gan, 2015: Evaluation of climate anomalies impacts on the Upper Blue Nile Basin in Ethiopia using a distributed and a lumped hydrologic model. J. Hydrol., 530, 225-240, https://doi.org/10.1016/j.jhydrol.2015.09.052.

Elshamy, M., L. Seierstad, and A. Sorteberg, 2009: Impacts of climate change on Blue Nile flows using bias-corrected GCM scenarios. Hydrol. Earth Syst. Sci., 13, 551-565, https://doi.org/ 10.5194/hess-13-551-2009.

Eum, H. I., A. Vasan, and S. P. Simonovic, 2012: Integrated reservoir management system for flood risk assessment under climate change. Water Resour. Manage., 26, 3785-3802, https:// doi.org/10.1007/s11269-012-0103-4.

FAO, 2015: Analysis on water availability and uses in Afghanistan river basins: Water accounting through remote sensing $(\mathrm{WA}+)$ in Helmand River Basin. FAO Project TCP/AFG/ $3402,50 \mathrm{pp}$.

Fu, P., and Q. Weng, 2016: A time series analysis of urbanization induced land use and land cover change and its impact on land surface temperature with Landsat imagery. Remote Sens. Environ., 175, 205-214, https://doi.org/10.1016/j.rse.2015.12.040.

Fu, Q., B. Li, Y. Hou, X. Bi, and X. Zhang, 2017: Effects of land use and climate change on ecosystem services in Central Asia's arid regions: A case study in Altay Prefecture, China. Sci. Total Environ., 607-608, 633-646, https://doi.org/10.1016/ j.scitotenv.2017.06.241.

Hossain, M. S., K. Roy, and D. Datta, 2014: Spatial and temporal variability of rainfall over the south-west coast of Bangladesh. Climate, 2, 28-46, https://doi.org/10.3390/cli2020028.

_ J. A. Dearing, M. M. Rahman, and M. Salhin, 2016: Recent changes in ecosystem services and human well-being in the Bangladesh coastal zone. Reg. Environ. Change, 16, 429-443, https://doi.org/10.1007/s10113-014-0748-z.

Huang, C., Y. Peng, M. Lang, I.-Y. Yeo, and G. McCarty, 2014: Wetland inundation mapping and change monitoring using Landsat and airborne LiDAR data. Remote Sens. Environ., 141, 231-242, https://doi.org/10.1016/j.rse.2013.10.020.

Imandoust, S. B., and S. H. Ghoreishi, 2016: A survey of the role of reliving of Hamoun wetland on the income of production of handicrafts among people living in Sistan Region. Int. J. Humanit. Soc. Sci., 6 (8), 269-274.

IPCC, 2001: Climate Change 2001: Synthesis Report. IPCC, $397 \mathrm{pp}$.

Kahsay, G., 2016: The effect of climate change and adaptation policy on agricultural production in Eastern Africa. Ecol. Econ., 121, 54-64, https://doi.org/10.1016/j.ecolecon.2015.11.016.

Langerwisch, F., T. Vaclavi, W. Bloh, T. Vetter, and K. Thonicke, 2018: Combined effects of climate and land-use change on the provision of ecosystem services in rice agro-ecosystems. Environ. Res. Lett., 13, 015003, https://doi.org/10.1088/1748-9326/ aa954d.

Li, Z., W. Liu, X. Zhang, and F. Zheng, 2009: Impacts of land use change and climate variability on hydrology in an agricultural catchment on the Loess Plateau of China. J. Hydrol., 377, 35-42, https://doi.org/10.1016/j.jhydrol.2009.08.007.

Loveland, T. R., and R. S. Defries, 2004: Observing and monitoring land use and land cover change. Ecosystems and Land Use Change, Geophys. Monogr., Vol. 153, Amer. Geophys. Union, 231-246.

Lu, D., and Q. Weng, 2009: Extraction of urban impervious surfaces from an IKONOS image. Int. J. Remote Sens., 30, 1297-1311, https://doi.org/10.1080/01431160802508985.

MacMartin, D., B. Kravitz, D. Keith, and A. Jarvis, 2014: Dynamics of the coupled human-climate system resulting from closed-loop control of solar geoengineering. Climate Dyn., 43, 243-258, https://doi.org/10.1007/s00382-013-1822-9.

Majdabadi, M., 2007: Population change in Sistan (in Persian). J. Environ. Stud., 61, 11.

Maleki, S., A. R. Soffianian, S. Soltani-Koupaei, S. Saatchi, S. Pourmanafi, and F. Sheikholeslam, 2016: Habitat mapping as a tool for water birds conservation planning in an arid zone wetland: The case study Hamoun wetland. Ecol. Eng., 95, 594-603, https://doi.org/10.1016/j.ecoleng.2016.06.115.

,,--- S. Pourmanafi, and S. Saatchi, 2018: Wetland restoration prioritizing, a tool to reduce negative effects of drought; An application of multicriteria-spatial decision support system (MC-SDSS). Ecol. Eng., 112, 132-139, https:// doi.org/10.1016/j.ecoleng.2017.12.031.

National Research Council, 2010: Informing an Effective Response to Climate Change. National Academies Press, 346 pp., https:// doi.org/10.17226/12784.

Partow, H., 2003: Sistan Oasis parched by drought. Atlas of Global Change, Oxford University Press, 144-145.

Ramsar, 2016: The List of Wetlands of International Importance. Ramsar, 54 pp., https://www.ramsar.org/sites/default/files/ documents/library/sitelist.pdf.

Rowhani, P., D. Lobell, M. Linderman, and N. Ramankutty, 2011: Climate variability and crop production in Tanzania. Agric. For. Meteor., 151, 449-460, https://doi.org/10.1016/ j.agrformet.2010.12.002.

Ruan, R., X. Feng, and Y. She, 2007: Fusion of RADARSAT SAR and ETM + imagery for identification of fresh water wetland. Proc. SPIE, 6752, 675221, https://doi.org/10.1117/ 12.760748

Saatchi, S., S. Asefi-Najafabady, Y. Malhi, L. Aragao, L. Anderson, R. Myneni, and R. Nemani, 2013: Persistent effects of a severe drought on Amazonian forest canopy. Proc. Natl. Acad. Sci. USA, 110, 565-570, https://doi.org/10.1073/ pnas. 1204651110.

Sajadi, Sh., M. Afrasyabi, and A. Eshnoei, 2014: Investgation the Sistan population. Geoghraphy, 7 (24), 88-102.

Scheraga, J., K. Ebi, J. Furlow, and A. Moreno, 2003: From science to policy: Developing responses to climate change. Climate Change and Human Health: Risk and Responses, WMO, 237-266.

Scullion, J., K. Vogt, A. Sienkiewicz, S. Gmur, and C. Trujillo, 2014: Assessing the influence of land-cover change and conflicting land-use authorizations on ecosystem conversion on the forest frontier of Madrede Dios, Peru. Biol. Conserv., 171, 247-258, https://doi.org/10.1016/j.biocon.2014.01.036.

Sexton, J., D. Urban, M. Donohue, and C. Song, 2013: Long-term land cover dynamics by multi-temporal classification across 
the Landsat-5 record. Remote Sens. Environ., 128, 246-258, https://doi.org/10.1016/j.rse.2012.10.010.

Shamohammadi, Z., and S. Maleki, 2011: The Life of Hamun. Jahad Daneshgahi, $250 \mathrm{pp}$.

Theobald, D., 2001: Land use dynamics beyond the American urban fringe. Geogr. Rev., 91, 544-564, https://doi.org/10.2307/3594740.

UNEP, 2002: Sistan oasis parched by drought. UNEP/DEWP/ GRID-Geneva, 11-21, 87 pp.

van der Pol, T., E. Ierland, S. Gabbert, H. Weikard, and E. Hendrix, 2015: Impacts of rainfall variability and expected rainfall changes on cost-effective adaptation of water systems to climate change. J. Environ. Manage., 154, 40-47, https:// doi.org/10.1016/j.jenvman.2015.02.016.

Wang, Y., B. Mitchell, J. Marzilli, G. Bonynge, Y. Zhou, and G. Shriver, 2009: Remote sensing of land-cover change and landscape context of the National Parks: A case study of the Northeast Temperate Network. Remote Sens. Environ., 113, 1453-1461, https://doi.org/10.1016/j.rse.2008.09.017.

Wang, Z., Z. Liu, K. Song, B. Zhang, S. Zhang, D. Liu, C. Ren, and F. Yang, 2009: Land use changes in Northeast China driven by human activities and climatic variation. Chin. Geogr. Sci., 19, 225-230, https://doi.org/10.1007/s11769-009-0225-7.

Wu, Y., S. Liu, T. Sohl, and C. Young, 2013: Projecting the land cover change and its environmental impacts in the Cedar
River Basin in the Midwestern United States. Environ. Res. Lett., 8, 024025, https://doi.org/10.1088/1748-9326/8/2/024025.

Ye, L., and N. Grimm, 2013: Modelling potential impacts of climate change on water and nitrate export from a mid-sized, semiarid watershed in the US Southwest. Climatic Change, 120, 419 431, https://doi.org/10.1007/s10584-013-0827-z.

Zhang, Y., S. Zhang, J. Xia, and D. Hua, 2013: Temporal and spatial variation of the main water balance components in the three rivers source region, China from 1960 to 2000. Environ. Earth Sci., 68, 973-983, https://doi.org/10.1007/s12665-012-1800-2.

Zhao, A., X. Zhu, X. Liu, Y. Pan, and D. Zuo, 2016: Impacts of land use change and climate variability on green and blue water resources in the Weihe River Basin of northwest China. Catena, 137, 318-327, https://doi.org/10.1016/ j.catena.2015.09.018

Zhou, F., X. Youpeng, C. Ying, G. Yuqin, and D. Jinkang, 2013: Hydrological response to urbanization at different spatiotemporal scales simulated by coupling of CLUE-S and the SWAT model in the Yangtze River Delta region. J. Hydrol., 485, 113-125, https://doi.org/10.1016/j.jhydrol.2012.12.040.

Zimmerman, R., and C. Faris, 2011: Climate change mitigation and adaptation in North American cities. Curr. Opin. Environ. Sustain., 3, 181-187, https://doi.org/10.1016/ j.cosust.2010.12.004. 